\title{
19 Shock States and Nitric Oxide
}

\author{
Hartmut Ruetten \\ and Christoph Thiemermann
}

\section{INTRODUCTION}

\section{Septic Shock}

\section{General Overview of Septic Shock}

Septic shock is the life-threatening complication of an overwhelming systemic infection in which the immune system releases inflammatory mediators resulting in pathophysiological vasodilatation, hematological abnormalities, and organ dysfunction and failure. Sepsis affects 300,000-500,000 patients annually in the United States (1). The prevalence of sepsis in hospitalized patients appears to have significantly increased over the past decade. Data from the Center for Disease Control and Prevention's National Hospital Discharge Survey show a 139\% increase in the discharge diagnosis of sepsis from 1977-1987 (2). The increase was especially marked for patients over $65 \mathrm{yr}$ of age (162\%). Despite improvements in intensive care management of critically ill patients, new antibiotics, and extensive research into the etiology of sepsis, the mortality of septic shock ranges from $20-55 \%(3,4)$. Mortality increases to $77-90 \%$ when shock occurs $(5,6)$.

Septic shock represents the combined effect of a variety of inflammatory and hormonal systems. A paradox of this disease entity is that the same inflammatory system responsible for defending us against the microbial invasion of tissues may produce shock when it is excessively activated. The initial clinical presentation of sepsis usually consists of fever, tachycardia, peripheral vasodilatation, hypotension, and oliguria. However, the key symptom of shock is a severe fall in blood pressure that is often associated with the dysfunction or failure of several important organs including lung, kidney, liver, and brain. Despite the observed increase in cardiac output, blood pressure is not maintained because of excessive vasodilatation. Treatment includes respiratory support to optimize tissue oxygenation, intravenous fluid administration, broad spectrum antimicrobial therapy, and vasopressor support.

The definition of septic shock is independent of the presence or absence of a multiple organ failure syndrome (MODS), which is defined as impaired organ function such that homeostasis cannot be maintained without intervention (7). Primary MODS is a direct result of a welldefined insult to a specific organ. Secondary MODS occurs as a consequence of an exaggerated host response, termed systemic inflammatory response syndrome (SIRS). The natural history of septic shock is often as follows: about $75 \%$ of deaths occur within hours to days after the onset of shock and are caused by therapy-resistant hypotension leading to the conclusion that peripheral vascular failure is the predominant factor that determines outcome (8).

From: Contemporary Cardiology, vol. 4: Nitric Oxide and the Cardiovascular System Edited by: J. Loscalzo and J. A. Vita (C) Humana Press Inc., Totowa, NJ 
The rest of the deaths occur days or weeks after the patient has recovered from hypotension, and the cause of death is multiple organ failure (9). Adult respiratory-distress syndrome (ARDS), followed by renal and hepatic failure is the most common sequence of events.

Septic shock is primarily initiated by components of the cell wall of Gram-positive or Gramnegative bacteria (10), but structural components of many other microorganisms generate a very similar spectrum of biological activities. Among the most studied are the peptidoglycans, a ubiquitous component of all bacterial cell walls, but particularly concentrated in Grampositive organisms (11). In addition, peptidoglycan and lipoteichoic acid from Staphylococcus aureus act in synergy to cause shock and multiple organ failure (12). Trehalose diesters produced by mycobacteria and corynebacteria and other Gram-positive bacterial products including lipomannans also cause lipopolysaccharide (LPS)-like effects $(13,14)$.

\section{The Cytokine Network}

Cytokines are a heterogeneous group of hormonelike proteins, produced by all organs and many cell types of the body that establish a communication network between various cells of each organ. Activation of the cytokine network follows a lag phase and is preceded by the activation of, e.g., the complement and kallikrein system. The study and the understanding of the cytokine network is complicated by the facts that (1) cytokines often induce the secretion of additional cytokines, (2) cytokines modulate the effects of other cytokines, resulting in additional, synergistic or inhibitory effects, or even a novel effect not seen with individual cytokines alone, (3) the sequence of cytokine exposure can influence target cell responses, and (4) cytokine effects may be dose-related with qualitatively different biologic effects seen at different doses (15).

The proinflammatory cytokines tumor necrosis factor- $\alpha$ (TNF- $\alpha$ ) and interleukin- $1 \beta$ (IL$1 \beta$ ) have been implicated in the pathophysiology of many cardiovascular disorders $(16-18)$ including circulatory shock (19-23). Administration of TNF- $\alpha$ alone, or in combination with low doses of endotoxin mimics several features of the pathophysiology of circulatory shock including hypotension and organ injury $(20,21)$. Intravenous administration of IL-1 either alone, or in combination with low doses of LPS or TNF- $\alpha$, also produces a shocklike state (19). Pronounced rises in the serum levels of TNF- $\alpha$ and IL-1 $\beta$ occur in experimental endotoxemia (21-25). More importantly, enhanced serum concentrations of TNF- $\alpha$ and IL-1 $\beta$ have been documented in human subjects with sepsis and septic shock (26), particularly in the early phase of shock. Moreover, TNF- $\alpha$ and IL-1 $\beta$ are secreted from the most severely affected organs (e.g. lung and liver) in patients with sepsis-related MODS (27). Higher concentrations of TNF- $\alpha$ and IL- $1 \beta$ are associated, not only with an increase in mortality rate, but also with an increased risk for subsequent ARDS and MODS (28). In addition, antibodies directed against TNF- $\alpha$ or IL- $1 \beta$ as well as agents which inhibit the release of TNF- $\alpha$, such as pentoxyfilline (29), or IL-1 $\beta$ exert protective effects in various animal models of endotoxin shock $(30,31)$. In contrast, clinical trials aimed at demonstrating a reduction in $28-\mathrm{d}$ mortality with such interventions have so far not met with the expected success. For instance, there is no convincing evidence that interventions aimed at reducing the effects of TNF- $\alpha$ (e.g., antibodies against TNF- $\alpha$, soluble TNF- $\alpha$ receptors, and so on) cause a significant reduction in 28-d mortality in patients with septic shock (32-35). Most notably, there is one recent report documenting that the treatment of septic patients with the TNF receptor: Fc fusion protein causes a dose-related increase in mortality (36). Similarly, clinical trials evaluating the effects of the IL-1 receptor antagonists have not resulted in a significant reduction in 28-d mortality $(37,38)$.

Although the aforementioned trials failed to provide evidence that any of the anticytokine interventions used caused a significant reduction in 28-d mortality, these studies nevertheless support the view that both TNF- $\alpha$ as well as IL-1 play a role in the pathophysiology of septic shock and indicate that anticytokine therapy may well be of benefit for certain groups of 
patients. The IL-1ra Phase III Sepsis Syndrome Group has recently reported that (1) there is a direct relationship between a patient's predicted risk of mortality at study entry and the efficacy of the IL-1 receptor antagonist (Il-1ra) in that (2) patients with a predicted risk of mortality of $<24 \%$ derived little benefit, whereas (3) IL-1ra reduced the risk of death in the first $2 \mathrm{~d}$ for patients with a predicted risk of mortality of $>24 \%$ (38). The reasons for the discrepancy in outcome between animal experiments and clinical trials are not entirely clear, but may include (1) relatively late intervention in clinical trials (vs. pretreatment in animal studies), (2) inhomogeneity of patients (e.g. differences in age, gender, causes of shock, severity of disease), or (3) the pharmacology (dose regimen, time of intervention, length of treatment) of the intervention chosen.

One could also argue that the pathophysiology leading to the circulatory failure, organ dysfunction and ultimately death in patients with septic shock is multifactorial and, hence, that interventions aimed at eliminating the detrimental effects of a single mediator ("singlebullet approach to the therapy of shock") - although useful in some acute animal models - are less likely (if not unlikely) to cause a significant reduction in 28-d mortality. Indeed, there is some evidence that the prevention of the formation of both TNF- $\alpha$ and IL-1 $\beta$ (e.g., with interferon- $\gamma$ or IL-10) is superior to prevention of the formation of either one of these cytokines in reducing mortality in rodent models of endotoxemia (39). Moreover, the reduction in survival afforded by a combination immunotherapy (antibody against TNF- $\alpha$, J5 antiserum against endotoxin, and a Pseudomonas O-serotype-specific opsonophagocytic monoclonal antibody) was greater than the one afforded by any combination of two antibodies or single antibody therapy (40). Recently, we demonstrated in a rat model of endotoxaemia that (1) coadministration of two polyclonal antibodies directed against either TNF- $\alpha$ or IL-1 or (2) neutralization of the effects of either TNF- $\alpha$ or IL-1 with one polyclonal antibody directed against both cytokines is superior in reducing the circulatory failure and MODS caused by endotoxin in the rat than a therapy with a single antibody directed against either cytokine (41). Having stated that some anticytokine therapies have caused an increase in mortality in patients with septic shock (38), it should also be noted that there may be potential hazards of combination immunotherapy. For instance, coadministration of IL-1ra and TNFbinding protein caused an increase in mortality in neutropenic rats with sepsis caused by Pseudomonas aeruginosa (42). Thus, further studies are warranted to gain a better understanding of the beneficial and adverse effects of combination immunotherapy in experimental endotoxemia and sepsis.

Another proinflammatory cytokine, interferon- $\gamma(\operatorname{IFN}-\gamma)$, is known as a mediator of septic shock. IFN- $\gamma$ is produced by activated lymphocytes and is a strong potentiator of the effect of TNF- $\alpha$, IL-1 $\beta$, or LPS in vitro and in vivo. Moreover, neutralization of IFN- $\gamma$ in mice prevents LPS-induced lethality (43).

\section{NITRIC OXIDE}

\section{General}

Nitric oxide $\left(\mathrm{NO}^{*}\right)$ is one of the smallest, biologically active messenger molecules. It is also a gaseous biological messenger, with a wide range of physiological and pathophysiological actions. The formation of $\mathrm{NO}^{*}$ from the guanidino nitrogen group of L-arginine is catalyzed by a group of isoenzymes termed nitric oxide synthases (NOSs) $(44,45)$. Although the three isoforms, endothelial cell NOS (ecNOS or NOS III), brain NOS (bNOS or NOS I), and inducible NOS (iNOS or NOS II), have different molecular weights and variable cofactor requirements, all of them are dependent on nicotinamide adenosine dinucleotide phosphate (NADPH), show similarities with cytochrome $\mathrm{P}_{450}$ reductase and also with the bacterial enzymes sulphite reductase and cytochrome $\mathrm{P}_{450} \mathrm{BM} 3$. The formation of NO* by NOS is linked to 
incorporation of molecular oxygen into the molecule (46). NOSs, in general, have the following catalytic activities: arginine, $N^{\omega}$-hydroxylase, $N^{\omega}$-hydroxyarginine, monooxygenase, NADPH oxidase, cytochrome c reductase, and dihydropterine reductase. NOS has been proposed to form $\mathrm{NO}^{\circ}$ and $\mathrm{L}$-citrulline in two steps, the first step being the formation of $N^{\mathrm{G}}$-hydroxyL-arginine, and the second, its three-electron oxidation. Both steps may utilize different heme-based oxidants, i.e., a perferryl species, $[\mathrm{FeO}]^{3+}$, for the first step and a peroxoiron species, $[\mathrm{FeOO}]^{+}$, for the second step. Both of these are produced when heme reacts with molecular oxygen $(47,48)$. All forms of NOS contain four prosthetic groups; flavin-adenine dinucleotide (FAD), flavin mononucleotide $(\mathrm{FMN})$, tetrahydrobiopterin $\left(\mathrm{BH}_{4}\right)$, and a heme complex, iron protoporphyrin IX. They are all dependent on calmodulin; in the inducible isoform calmodulin is already present in a tightly bound form.

All of the NOS isoforms can be inhibited to a variable degree, with $N^{\mathrm{G}}$-substituted L-arginine analogs, e.g., $N^{\mathrm{G}}$-monomethy-L-arginine (L-NMMA). Some NOS inhibitors show some isoform selectivity; e.g., calmodulin-binding agents such as trifluoperazine do not inhibit the calmodulin-independent (iNOS) isoform. For reasons that are not entirely understood, some of the L-arginine analog NOS inhibitors also show limited isoform selectivity: $N^{\mathrm{G}}$-cyclopropylL-arginine, $N^{\mathrm{G}}$-nitro-L-arginine, and its methyl ester, L-NAME (after hydrolysis), show some selectivity toward the constitutive NOS, whereas L-NMMA, $N^{\mathrm{G}}$-amino-L-homoarginine and $N^{\mathrm{G}}$-amino-L-arginine are approximately equipotent inhibitors of ecNOS and iNOS activity $(49,50)$. Moreover, prolonged exposure of NOS to L-NMMA results in an irreversible inactivation of the enzyme, and this is preceded by an NADPH-independent hydroxylation of the inhibitor (51).

The inducible isoform of NOS (iNOS) is, under physiological conditions, absent from mammalian cells, but is induced by proinflammatory stimuli, such as bacterial lipopolysaccharide or the cytokines TNF- $\alpha$, IL- $1 \beta$, or IFN- $\gamma$, as well as their combination. In contrast to ecNOS and bNOS, however, iNOS tightly binds calmodulin to exert its full biological activity. Thus, iNOS is not regulated by intracellular calcium levels and produces a longlasting generation of large amounts of $\mathrm{NO}^{*}$ (in the $\mathrm{n} M$ range) $(52,53)$. In contrast to ecNOS or bNOS, the availability of extracellular L-arginine can be rate limiting to obtain a maximal generation of $\mathrm{NO}^{\circ}$ by iNOS (54).

Since the discovery in 1990 that an enhanced formation of endogenous NO• contributes to (1) the hypotension caused by endotoxin and TNF- $\alpha(55,56),(2)$ the vascular hyporesponsiveness to vasoconstrictor agents (also termed "vasoplegia") $(57,58)$, and (3) the protection of liver integrity in rodents with sepsis (59), there has been an increasing interest in the role of $\mathrm{NO}^{\circ}$ in the pathophysilogy of animal and humans with septic shock. In addition to endotoxic shock, an enhanced formation of $\mathrm{NO}^{\bullet}$ also occurs in other types of shock including Gram-positive, hemorrhagic, traumatic, and anaphylactic shock (60). The overproduction of $\mathrm{NO}^{*}$ in animal models of circulatory shock is due to an early activation of ecNOS (which is transient) and the delayed induction of iNOS activity in macrophages (host defense) and vascular smooth muscle cells (hypotension, vascular hyporeactivity, maldistribution of blood flow) (61). The finding that inhibitors of NOS activity (e.g., L-NAME, L-NMMA) attenuate the hypotension and vasoplegia caused by endotoxin in animals $(56,58)$, together with the discovery that mice that are deficient in iNOS (iNOS knockout mice) exhibit only a minor fall in blood pressure when challenged with endotoxin $(62,63)$, support the hypothesis that an overproduction of $\mathrm{NO}^{\circ}$ by iNOS contributes to the circulatory failure in septic shock. It is, however, less clear, whether increased formation of $\mathrm{NO}^{\bullet}$ also contributes to the organ injury and dysfunction caused by endotoxin. These data support the view that reducing the enhanced formation of $\mathrm{NO}^{\circ}$ by iNOS may become a useful therapeutic approach in sepsis/ septic shock. In principle, there are two approaches to achieve this goal, i.e., inhibition of iNOS induction and/or inhibition of the activity of iNOS, by inhibiting the enzyme itself or one of its cofactors. 


\section{Inhibition of the Induction of iNOS}

The mechanism of iNOS induction is not fully understood. It clearly involves the transcription of mRNA and novel protein biosynthesis. The sequencing of the DNA regions upstream to the NOS gene (i.e., the promoter region) revealed separate promoter regions for the induction of iNOS by LPS and IFN- $\gamma(64)$. There is increasing evidence for the involvement of the nuclear transcription factor NF- $\mathrm{KB}(65,66)$, tyrosine kinase activation (67-69), microtubule depolimerization, and protein kinase $\mathrm{C}$-epsilon (70) in the induction process.

Induction of iNOS can be inhibited by numerous agents including glucocorticoids, thrombin, or ethanol; macrophage deactivation factor and transforming growth factor $\beta$ (TGF- $\beta$ ), platelet-derived growth factor, endothelin-1, IL-4, IL-8, IL-10, and IL-13 (53, 71-75). Inhibitors of protein kinase $\mathrm{C}(\mathrm{PKC})$, or of protein tyrosine kinase $(68,69,76)$, or of the activation of NF- $\mathrm{KB}(66,77)$ can also inhibit the induction of iNOS. An increase in cyclic adenosine monophosphate (cAMP) induces iNOS in vascular smooth muscle cells (VSMCs) and rat renal mesangial cells $(78,79)$, whereas prolonged elevation in intracellular cAMP levels in macrophages inhibits iNOS induction (80). NO ${ }^{\bullet}$ itself can also regulate its activity, both by inhibiting iNOS activity (81) and by downregulating iNOS mRNA (82).

\section{Inhibition of Protein Tyrosine Kinase}

Phosphorylation of proteins on tyrosine residues by protein tyrosine kinases plays an important role in the regulation of cell proliferation, cell differentiation, and signaling processes in cells of the immune system. The receptor tyrosine kinases participate in transmembrane signaling, whereas the intracellular tyrosine kinases take part in the signal transduction to the nucleus. Enhanced activity of tyrosine kinases has been implicated in the pathophysiology of many diseases associated with local (atherosclerosis, psoriasis) or systemic inflammation including sepsis and septic shock (83).

Endotoxin LPS causes the phosphorylation of tyrosine kinases in macrophages (and other target cells) (84), resulting in the release of proinflammatory cytokines including TNF- $\alpha$, IL-1, and IFN- $\gamma$. In human monocytes activated with LPS, inhibition of tyrosine kinase activity with genistein or herbimycin A attenuates the expression of the mRNA's for IL-1, TNF- $\alpha$, and IL-6 (85). TNF- $\alpha$ and IL-1 also induce the phosphorylation of tyrosine in target cells $(86,87)$ and when given to animals mediate many of the effects of LPS (see ref. 23). Inhibition of the activity of tyrosine kinases by tyrphostin AG126 prevents (when given $2 \mathrm{~h}$ prior to LPS) the mortality caused by LPS in mice, but is less effective when given together with LPS (88). Tyrphostin AG556, which is more lipophilic than AG126, prevents the mortality caused by endotoxin in mice when given as late as $2 \mathrm{~h}$ after injection of endotoxin (89). The mechanism(s) of these beneficial effects of tyrosine kinase inhibitors in shock is largely unknown. We demonstrated that several chemical distinct tyrphostins, i.e., AG126, AG490, AG556, AG1641, or A1 or the isoflavone genistein prevent (1) the circulatory failure (hypotension and vascular hyporeactivity to noradrenaline), (2) the multiple organ dysfunction (liver and pancreatic dysfunction/injury, lactacidosis, hypoglycemia) (Fig. 1), as well as (3) the induction of iNOS protein and activity in rats with endotoxic shock. The mechanism(s) by which the tyrosine kinase inhibitors exert the beneficial effects in shock warrants further investigation, but may involve the prevention of the formation of TNF- $\alpha$ and the expression of iNOS protein (76).

\section{Inhibition of the Nuclear Transcription Factor NF-kB}

The expression of inducible genes in eukaryocytes is largely controlled by proteins, such as NF- $\kappa \mathrm{B}$, which activate transcription $(90,91)$. NF- $\kappa \mathrm{B}$ is itself activated by the exposure of cells to endotoxin or TNF- $\alpha$, IL-1, IL-2, or phorbol 12-myristate 13-acetate (PMA) (92-95). $\mathrm{NF}-\kappa \mathrm{B}$ is a family of dimers, all of which are composed of members of the Rel/NF- $\kappa \mathrm{B}$ family 


\section{A}
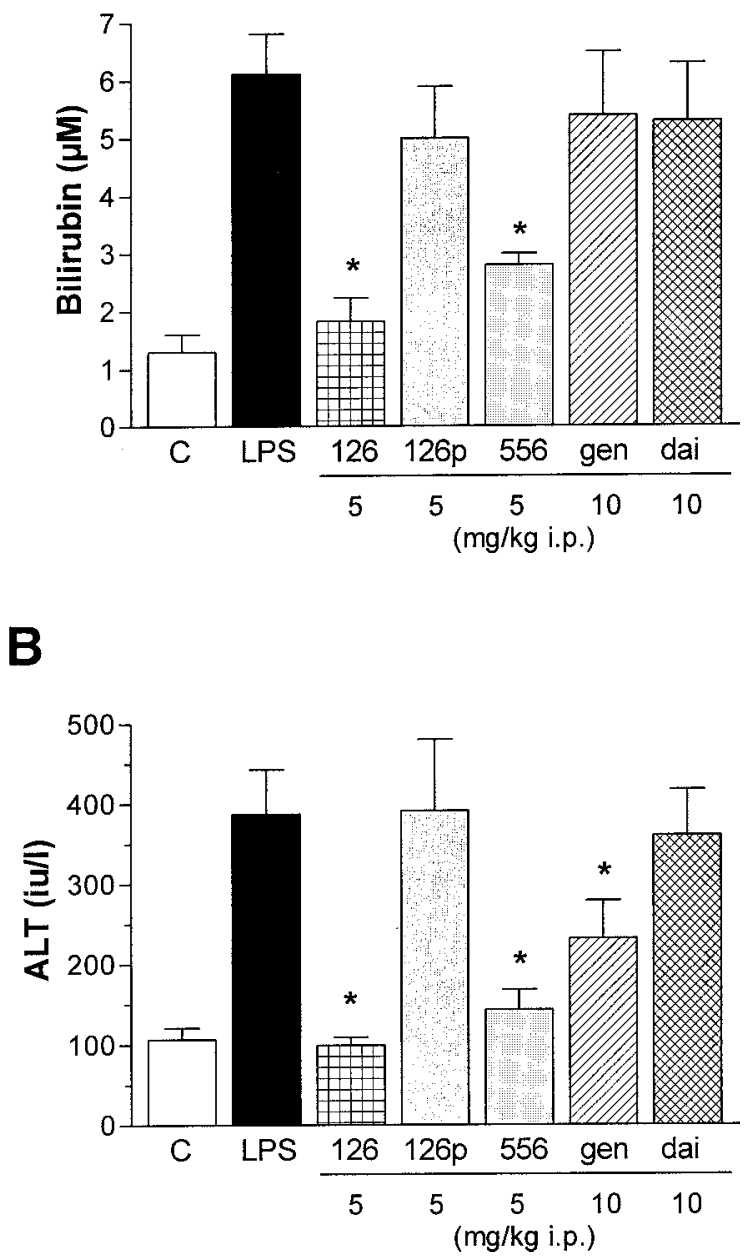

Fig. 1. Effect of different tyrosin kinase inhibitors on the LPS-induced increases in the serum concentrations of (A) bilirubin, and (B) ALT (indicator of liver injury) at $6 \mathrm{~h}$ after the injection of E. coli lipopolysaccharide (LPS; $10 \mathrm{mg} / \mathrm{kg}$ iv). Different groups of rats received (1) vehicle (50\% DMSO/PBS, $1 \mathrm{ml} / \mathrm{kg}$ ip) rather than LPS (C, $n=4),(2)$ vehicle (50\% DMSO/PBS, $1 \mathrm{ml} / \mathrm{kg}$ ip) plus LPS (LPS; $n=6$ ), (3) LPS plus tyrphostin AG126 (126; $n=6)$, (4) LPS plus delayed administration of tyrphostin AG126 (126p; $n=4)$, (5) LPS plus tyrphostin AG556 (556; $n=6)$, (6) LPS plus genistein (gen; $n=6$ ), or (7) LPS plus daidzein (dai; $n=5$ ). Data are expressed as mean $\pm \mathrm{SEM}$ of $n$ observations. ${ }^{*} p<0.05$ represents significant difference when compared to LPS controls.

of polypeptides. The most frequent form of NF- $\kappa \mathrm{B}$ is a dimer composed of two DNA-binding proteins, i.e., NF- $\mathrm{\kappa B} 1$ (or p50) and RelA (or p65), although other dimeric combinations also exist (96). Under physiological conditions, NF- $\mathrm{KB}$ is held (in an inactive form) in the cytoplasm by the inhibitory protein IKB- $\alpha$, which avidly binds to most heterodimers including the NF- $\mathrm{KB} 1 /$ Rel A heterodimer. This inhibitory subunit can be considered to be a cytoplasmatic anchor, as it prevents the nuclear uptake of NF- $\kappa B$. Activation of NF- $\kappa B$ involves the release

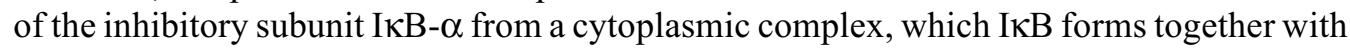
the DNA-binding subunit RelA and NF- $\kappa B 1(97,98)$. Activation of NF- $\kappa B$ allows NF- $\kappa B$ to translocate to the nucleus and to induce the expression of specific genes. The cascade of events 


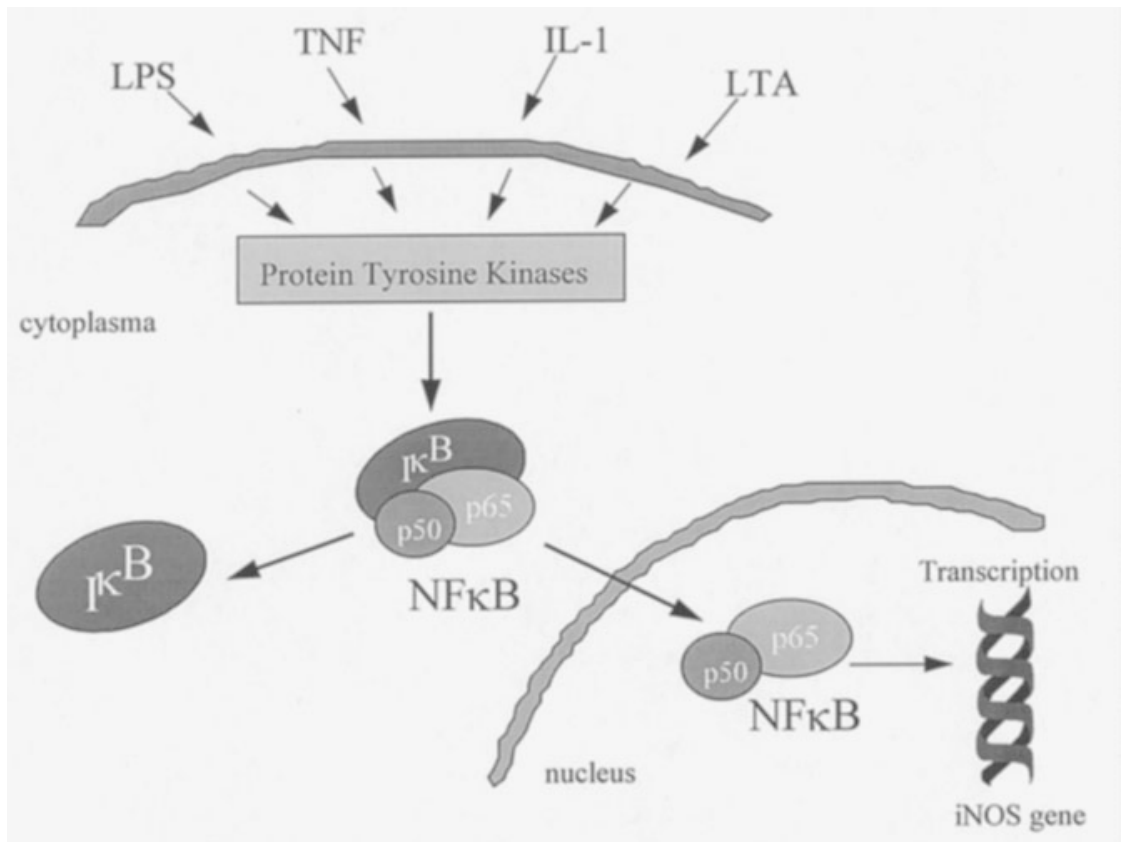

Fig. 2. Hypothetical signal transduction pathway for the induction of iNOS.

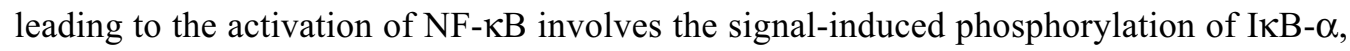
resulting in its proteolytic degradation and the release of NF- $\kappa B$ from its cytoplasmatic anchor. NF- $\kappa \mathrm{B}$ then translocates into the nucleus, where it binds to different gene promotors and, hence, induces a large number of genes $(99,100)$. The proteolytic degradation of IкB- $\alpha$ is inhibited by the cysteine protease inhibitor calpain inhibitor I, but not by other inhibitors of serine and cysteine proteases, such as chymostatin or leupeptin (101).

There is evidence that the expression of the gene for iNOS involves the activation of NF- $\mathrm{KB}$ (Fig. 2), and the expression of iNOS in vitro caused by LPS or lipoteichoic acid is prevented by several agents that interfere with the activation of NF- $\mathrm{BB}$, such as the radical scavanger rotenone, butylated hydroxyanisole, and pyrroidine dithiocarbamate (PDTC) $(66,77)$. Moreover, aspirin, sodium salicylate, and N-acetylcysteine attenuate the activation of NF- $\mathrm{KB}$ by a mechanism that involves antioxidant effects of these agents. Interestingly, IL-10 (which has been reported to improve survival in animal models of endotoxin shock) also prevents the activation of NF- $\mathrm{KB}$ (102). Recently, we demonstrated that inhibition of the activation of NF- $\kappa \mathrm{B}$ in vivo by calpain inhibitor I and dexamethasone, but not the serine and cysteine protease inhibitor chymostatin, attenuate (1) the circulatory failure (hypotension and vascular hyporeactivity to noradrenaline), (2) the multiple organ dysfunction (liver and pancreatic injury/dysfunction, increase in lactate, hypoglycemia), and (3) the induction of iNOS protein and activity (in lung and liver) of rats with endotoxic shock (Figs. 3 and 4). We proposed that the reduction of the expression of iNOS contributes to the beneficial effects of calpain inhibitor I. These results support the view that attenuation or prevention of the activation of NF- $\kappa$ B with calpain inhibitor I may be useful in the therapy of circulatory shock or of disorders associated with local or systemic inflammation (103).

It should be noted that the molecular mechanism by which dexamethasone, an agent that is well known to inhibit the endotoxin-mediated induction of iNOS in vitro and in vivo (104), exerts beneficial effects in endotoxin shock, is not well understood, but there is recent evidence that glucocorticoids inhibit the action of the transcription factors AP-1 and NF- $\mathrm{KB}$ (102). Interestingly, there is recent evidence that there is a protein-protein interaction between the 


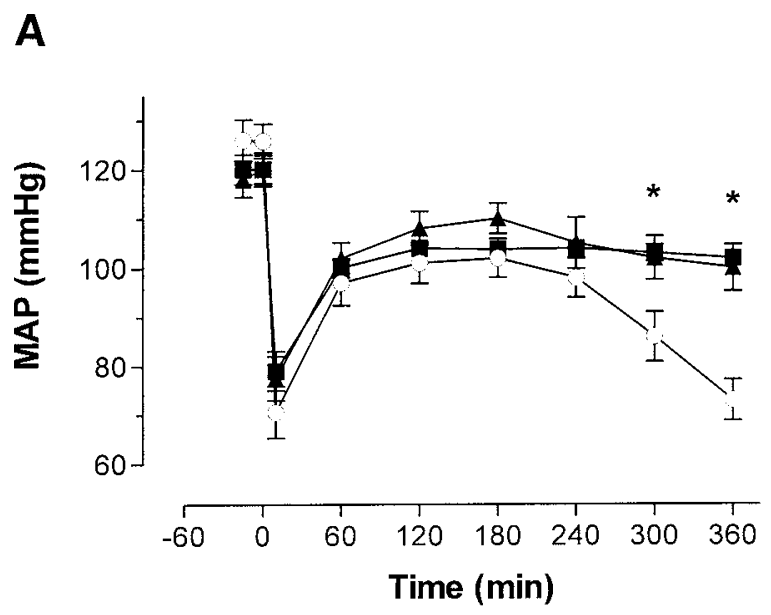

B

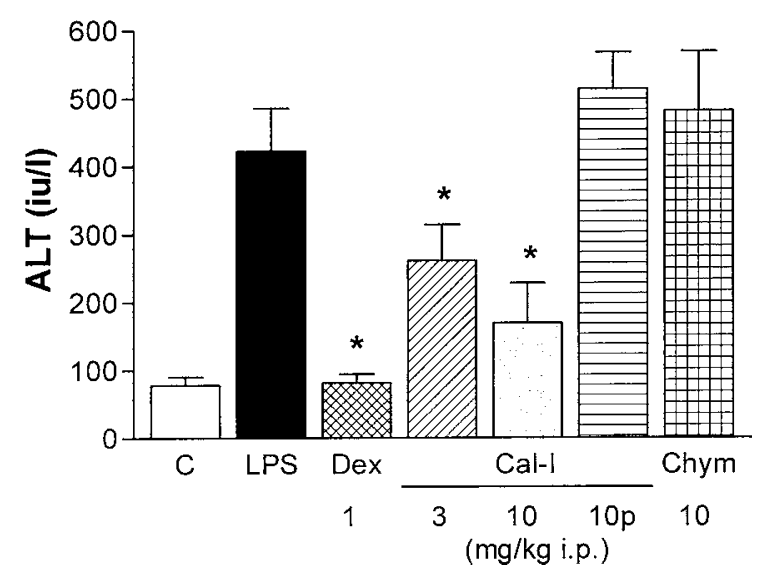

Fig. 3. Calpain inhibitor I or dexamethasone prevent (A) the delayed circulatory failure (fall in mean arterial blood pressure; MAP) and (B) liver failure (increase in alanine aminotransferase; ALT) in rats with septic shock. Different groups of animals received vehicle for $E$. coli lipopolysaccharide (LPS) (C, $n=4)$, LPS alone (LPS, $10 \mathrm{mg} / \mathrm{kg}$ iv, $n=10$, open circles), LPS plus $1 \mathrm{mg} / \mathrm{kg}$ ip dexamethasone (Dex, $n=6$; filled squares), LPS plus $3 \mathrm{mg} / \mathrm{kg}$ ip of calpain inhibitor I (Cal-I, 3; $n=6$ ), LPS plus $10 \mathrm{mg} / \mathrm{kg}$ ip of calpain inhibitor I (Cal-I, $10 ; n=7$, filled triangles), LPS plus late administration at $2 \mathrm{~h}$ after LPS of $10 \mathrm{mg} / \mathrm{kg}$ ip of calpain inhibitor I (Cal-I, 10p; $n=4)$ or LPS plus chymostatin (Chym; $n=5$ ). Data are expressed as mean \pm SEM of $n$ observations. ${ }^{*} p<0.05$ represents significant difference when compared to LPS controls.

activated glucocorticoid receptor and NF- $\mathrm{B}$, resulting in prevention of its binding to the $\kappa \mathrm{B}$ consensus motif on the promotor of its target genes. In addition, glucocorticoids enhance the formation of $\mathrm{I} \kappa \mathrm{B} \alpha$, which results in an excess of this inhibitory factor in the nucleus and

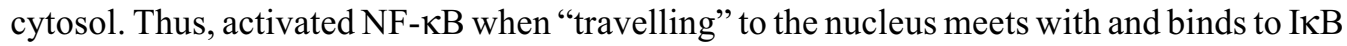
to form its "dormant" (inactive) cytosolic form (for a detailed review, see ref. 102).

Although there is good evidence that TNF- $\alpha$ (and other proinflammatory cytokines) cause the activation and translocation of $N F-\kappa B$ into the nucleus, there is also evidence that (1) tyrosine phosphorylation itself plays an important role in the activation of NF- $\kappa \mathrm{B}$ and that (2) tyrosine kinase inhibitors diminish the activation of NF- $\kappa B$. For instance, higher concentrations of genistein $(100 \mu M)$ attenuate the translocation of NF- $\kappa \mathrm{B}$ in rat pancreatic beta cells activated with IL-1 (105). Herbimycin A also suppresses the activation of NF- $\kappa B$ and the 

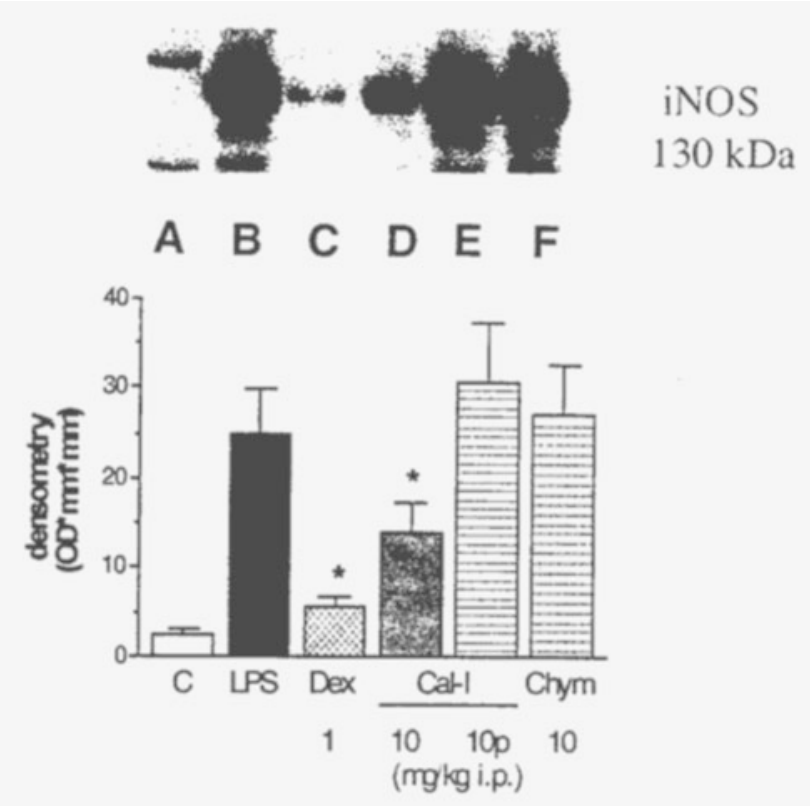

Fig. 4. Effect of calpain inhibitor I on the expression of iNOS protein in lung homogenates at $6 \mathrm{~h}$ after administration of endotoxin. Different groups of animals received vehicle (C) for E. coli lipopolysaccharide (LPS; lane A), LPS alone (LPS; lane B), LPS plus $1 \mathrm{mg} / \mathrm{kg}$ ip dexamethasone (Dex; lane C), LPS plus $10 \mathrm{mg} / \mathrm{kg}$ ip of calpain inhibitor I (Cal-I; lane D), LPS plus late administration at $2 \mathrm{~h}$ after LPS of $10 \mathrm{mg} / \mathrm{kg}$ ip of calpain inhibitor I (Cal-I; lane E) or LPS plus chymostatin (Chym; lane F). Similar results of the Western blots were seen using tissue extracts from two other animals with the same treatment. ${ }^{*} p<0.05$ represents significant difference when compared to LPS controls.

phosphorylation of Janus kinase 2 (JAK2) caused by LPS and interferon- $\gamma$ in C6 glial cells, respectively (106). Herbimycin A also reduces the activation of NF- $\kappa B$ caused by IL-1 and phorbol 12-myristate 13-acetate (PMA) in thymoma cells or by PMA in Jurkat T cells. However, the inhibition of the activation of NF- $\mathrm{KB}$ by herbimycin $\mathrm{A}$ is secondary to a modification of the p50 subunit on cysteine 62 in the NF- $\mathrm{KB}$ complex, but is independent of the inhibition of tyrosine kinase activity (107). The expression of matrix metalloproteinase-9 (MMP-9) caused by IL-1 in glomerular mesangial cells is also (at least in part) attributable to tyrosine kinase-mediated activation of NF- $\kappa \mathrm{B}$ (108). The prevention by genistein and herbimycin A of the expression of COX-2 in rat mesangial cells is not caused by inhibition of the activation of NF- $\kappa B$, suggesting that an upstream tyrosine kinase pathway may not be required for the IL-1-induced activation of NF- $\mathrm{KB}$ in these cells (109). Most notably, stimulation of Jurkat $\mathrm{T}$ cells with the protein tyrosine phosphatase inhibitor and $\mathrm{T}$-cell activator pervanadate leads to activation of NF- $\kappa \mathrm{B}$ resulting from tyrosine phosphorylation, but not degradation of $\mathrm{I}-\kappa \mathrm{B} \alpha$. It has therefore been suggested (110) that the tyrosine phosphorylation of I- $\kappa \mathrm{B} \alpha$ represents a proteolysis-independent mechanism of NF- $\mathrm{KB}$ activation that directly couples $\mathrm{NF}-\kappa \mathrm{B}$ to cellular tyrosine kinase. Thus, it is possible that the tyrosine kinase inhibitors prevent the activation of NF- $\kappa \mathrm{B}$ either by an indirect (e.g., prevention of the formation of TNF- $\alpha$ ) or by a direct effect. Suppression of the activation of NF- $\kappa B$ by tyrosine kinase inhibitors may well result in a reduced expression of enzymes (e.g., iNOS, COX-2, cPLA $\mathrm{C}_{2}$, and so forth), cytokines (TNF- $\alpha$, IL-1 $\beta$, IL-6, and so on), chemokines (IL-8, RANTES, and the like) or adhesion molecules (ICAM-1, VCAM-1, E-selectin) known to play an important role in the pathophysiology of endotoxin shock (111).

It should be stressed, however, that all of the foregoing therapeutics must be administered prior to the application of endotoxin or at least prior to the induction of iNOS (e.g., approx 
Table 1

Possible Effects of Administration of NOS Inhibitors in Septic Shock

\begin{tabular}{ll}
\hline Beneficial & \multicolumn{1}{c}{ Adverse } \\
\hline Increased blood pressure & Excessive vasoconstriction \\
Restores responsiveness to pressor agents & Pulmonary hypertension \\
Cardiac output return to baseline values & Fall in cardiac output \\
Decreased production of peroxynitrite & Increased platelet adhesiveness \\
Attenuation of inhibition of mitochondrial respiration & Increased neutrophil adhesion \\
Improved organ function & Worsened organ function \\
Improved survival & Reduction in survival \\
\hline
\end{tabular}

$2 \mathrm{~h}$ after endotoxin) to prevent the severe delayed circulatory failure, the MODS as well as the induction of iNOS caused by endotoxin in animal models of SIRS. For example, the administration of dexamethasone, calpain inhibitor I, or tyrosine kinase inhibitors to rats $2 \mathrm{~h}$ after the injection of endotoxin neither exerts beneficial effects on hemodynamic or organ injury nor inhibits the induction of iNOS $(76,103,112,113)$. As for the cytokine antibodies, the timely administration of inhibitors of the induction of iNOS will be crucial to achieve beneficial effects in patients with severe sepsis. Practically, one needs to determine the time between the induction of iNOS (or early phases of the syndrome) and the administration of the inhibitors of iNOS induction. This supports the view that drugs that directly inhibit iNOS activity are useful tools, whereas the use of agents that inhibit the induction of iNOS may be less useful.

\section{Inhibition of NOS Activity}

Since the discovery in 1990 that an enhanced formation of endogenous NO resulting from the induction of iNOS contributes to the hypotension caused by endotoxin and TNF- $\alpha$ (56) and vascular hyporesponsiveness to vasoconstrictor agents (vasoplegia) (57) and the finding that inhibitors of NOS activity attenuate the hypotension and vasoplegia in endotoxemia, together with the discovery that mice, in which the iNOS gene has been inactivated by genetargeting (iNOS knockout mice), exhibit only a minor fall in blood pressure when challenged with endotoxin $(62,63)$ support the hypothesis that an overproduction of NO* by iNOS contributes to the circulatory failure in septic shock. It is, however, less clear whether increased formation of $\mathrm{NO}^{\circ}$ caused by the induction of iNOS may cause cellular damage in a paracrine or autocrine fashion $(114,115)$, and, hence, also contributes to the organ injury and dysfunction caused by endotoxin in septic shock. It is noteworthy that the formation of NO by eNOS and potentially also by iNOS also exerts beneficial effects in shock including vasodilatation, prevention of platelet and leukocyte adhesion, maintenance of microcirculatory blood flow, and augmentation of host defense. Thus, it is not surprising that basic and clinical scientists have advocated the use of contrasting therapeutic approaches including inhibition of NOS activity, enhancement of the availability of $\mathrm{NO}^{*}\left(\mathrm{NO}^{*}\right.$ donors, $\mathrm{NO}^{*}$ inhalation) or a combination of both approaches (for review see refs. 60,61, and 116). The following paragraphs highlight some of the effects and side effects of inhibitors of NOS activity (Table 1) in animal models of septic shock.

\section{Inhibition of NOS Activity in Animal Models of Shock: Effects and Side Effects}

Although there is good evidence that endotoxemia or sepsis in rodents results in the induction of iNOS (in various tissues) leading to an increase in the plasma levels of nitrite/ nitrate (from 20 up to $600 \mu M$ ) (149), there is limited information regarding the time-course of iNOS induction, the degree of iNOS activity (in tissues) or even the plasma levels of nitrite/ nitrate in large animal models (pig, dog, sheep, baboon) of shock or in humans with sepsis 
and septic shock. Clearly, sepsis (or endotoxemia) results in an increase in the plasma levels of nitrite/nitrate in these species. Thus, when evaluating the role of $\mathrm{NO}^{*}$ or elucidating the effects of NOS inhibitors in animal models of shock, one needs to consider that (1) many of the models used are acute, nonresuscitated, hypodynamic models of shock, (2) the effects (and side effects) of nonselective inhibitors of NOS activity will greatly vary depending on the degree of iNOS induction in the species, and (3) any observed effects of the respective NOS inhibitor used will obviously depend on the chosen dose regimen and timing of the intervention.

The N-substituted L-arginine analog L-NMMA was the first agent reported to inhibit NOS activity. Following the discovery in 1990 that L-NMMA exerts beneficial hemodynamic effects in animal models of endotoxemia $(55,56)$, many subsequent studies aimed at elucidating the role of $\mathrm{NO}^{\circ}$ in septic shock have used the NOS inhibitor L-NAME rather than L-NMMA, as L-NAME is cheap and readily available. In contrast to L-NMMA, L-NAME is a relatively selective inhibitor of eNOS rather than iNOS activity (117). Hence, higher doses of this agent may cause excessive vasoconstriction (particularly in the pulmonary, renal, and myocardial vascular bed) and enhance the incidence of both microvascular thrombosis and neutrophil adhesion in the endothelium. Thus, L-NAME reduces oxygen delivery and exacerbates organ injury in (many, but not all) animal models of endotoxic shock (136). These results are not necessarily solely due to the use of very large amounts of L-NAME, but rather a reflection of the fact that L-NAME is a more selective inhibitor of eNOS than iNOS activity. In rats with endotoxemia, infusion of very low doses of L-NAME (e.g., 0.03-0.3 mg/ $\mathrm{kg} / \mathrm{h}$ ) results in a dose-related increase in blood pressure (because of inhibition of eNOS activity) without reducing the rise in the plasma levels of nitrite/nitrate (an indicator of NOS activity) or the organ injury caused by endotoxin (118) (Fig. 5). However, it should be noted that in the kidney, eNOS may have protective (antithrombotic) actions in some models of LPS-induced renal damage (146). Indeed, infusion of very low doses $(30-50 \mu \mathrm{g} / \mathrm{kg} / \mathrm{min})$ of L-NAME cause (1) a reduction in renal cortical blood flow without causing an increase in blood pressure in the rat (119), and (2) a significant increase in pulmonary vascular resistance caused by endotoxin in the pig (120). Although L-NAME may be suitable to inhibit the generation of $\mathrm{NO}^{*}$ by all three isoforms of NOS, this agent should not be used as a therapeutic intervention in such diseases as septic shock, where an overproduction of NO by iNOS has been implicated as an underlying cause of the pathology.

In contrast to L-NAME, L-NMMA is an endogenous substance present in the urine of both animals and humans. Although L-NMMA inhibits all isoforms of NOS to a variable degree, it is a more potent inhibitor of iNOS than eNOS activity. L-NMMA is a competitive inhibitor of the binding of L-arginine to NOS and, hence, excess of L-arginine reverses the inhibition of NOS activity by L-NMMA. The effects of L-NMMA in models of shock vary from "very beneficial" to "moderately beneficial with some adverse effects" to "detrimental" (often caused by marked inhibition of eNOS activity) $(117,136)$. Clearly, the observed results depend on the dose of L-NMMA as well as the model of shock used. When given after the onset of hypotension, infusions of relatively low doses of L-NMMA (3-10 mg/kg/h) have been convincingly demonstrated to exert beneficial hemodynamic effects in rodents, sheep, dogs, and baboon models of endotoxemia and sepsis. For instance, in conscious baboons, administration of live Escherichia coli bacteria resulted in a significant increase in the serum levels of biopterin, neopterin, and nitrate, suggesting an induction of guanosine triphosphate (GTP) cyclohydrolase I and iNOS. In this model, infusion of L-NMMA ( $5 \mathrm{mg} / \mathrm{kg} / \mathrm{h})$ attenuated the rise in the serum levels of nitrate and creatinine, the hypotension and fall in peripheral vascular resistance and the substantial 7-d mortality caused by severe sepsis in this species (Daryl Rees and Heinz Redl, personal communication). These findings clearly document that the circulatory failure caused by septic shock in baboons is largely mediated by an enhanced formation of $\mathrm{NO}^{*}$ by iNOS and that inhibition of iNOS with L-NMMA improves outcome in this model. 

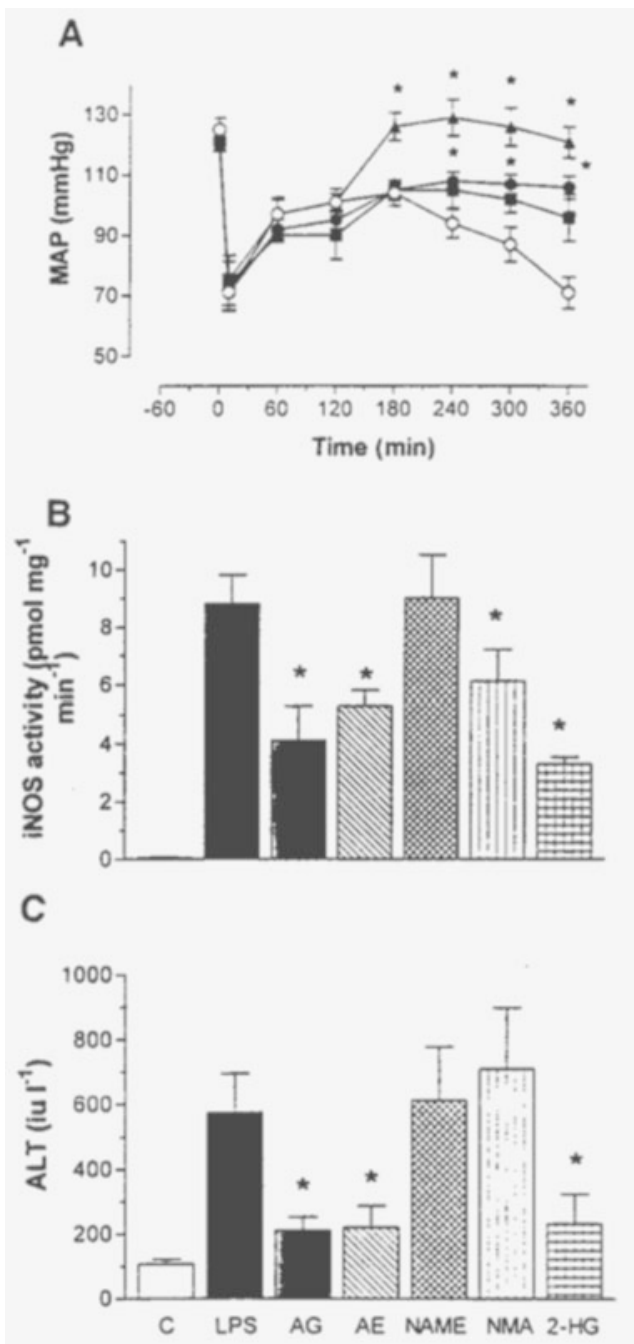

Fig. 5. (A) Effect of aminoguanidine (AG, $n=8$; filled squares), or aminoethyl-isothiurea (AE, $n=8$; filled circles) or $N^{\omega}$-nitro-L-arginine methyl ester (L-NAME, $n=6$; filled triangles) on the fall in mean arterial blood pressure (MAP) caused by E. coli lipopolysaccharide (LPS; $10 \mathrm{mg} / \mathrm{kg}$ iv) in the anesthetized rat. The alterations in MAP (over time) of rats that were pretreated with vehicle (for the drugs) and then received LPS are also shown (LPS control, $n=10$; open circles). (B) Effect of different NOS inhibitors on the increase in iNOS activity and $(\mathbf{C})$ the serum concentration of alanine aminotransferase (ALT) in rats with septic shock. Different groups of LPS rats were infused for $4 \mathrm{~h}$ with vehicle $(n=10)$, AG $(n=8), \mathrm{AE}(n=8), N^{\omega}$-nitro-L-arginine methyl ester (NAME, $n=6), N^{\mathrm{G}}$-methyl-L-arginine (NMA, $n=6$ ) or 1-amino-2-hydroxy-guanidine (2-HG, $\left.n=10\right)$. The infusion of drug or vehicle was started at $2 \mathrm{~h}$ after LPS. Data are expressed as mean $\pm \mathrm{SEM}$ of $n$ observations. ${ }^{*} p<0.05$ represents a significant reduction in concentration/activity when compared to LPS rats.

The observed beneficial effects of L-NMMA in animal models of septic shock stimulated the search for selective inhibitors of iNOS activity. In the last years, several compounds including aminoguanidine, certain isothiourea derivates (e.g., aminoethyl-isothiurea), acetamidines (e.g., 1400W) and amino acid analogs (L-NIL). Aminoguanidine was the first relatively selective inhibitor of iNOS activity discovered (121). Although aminoguanidine is a more potent inhibitor of iNOS than of eNOS activity in vitro and in vivo, aminoguanidine is not a very potent inhibitor of iNOS activity. Aminoguanidine attenuates the delayed 
hypotension in rats (122) and rabbits (123) with endotoxin shock and improves survival in mice challenged with endotoxin (122). Aminoguanidine and its analog 1-hydroxy-2-guanidine also attenuate the liver injury and hepatocellular dysfunction caused by endotoxin in the rat $(122,124)$ (Fig. 5). In rats with endotoxic shock, aminoguanidine also reduces the increase in pulmonary transvascular flux (125). The interpretation of the mechanism(s) by which aminoguanidine exert these beneficial effects is difficult, as aminoguanidine is not a specific inhibitor of iNOS activity but has many other pharmacological properties including inhibition of (1) histamine metabolism, (2) polyamine catabolism, (3) the formation of advanced glycosylation end products, and (4) catalase activity (as well as other copper- or iron-containing enzymes) (126-129). Interestingly, aminoguanidine also prevents the expression of iNOS protein by a hitherto-unknown mechanism (130). Thus, aminoguanidine has to be regarded as an agent that (1) is a relatively selective, but not very potent inhibitor of iNOS activity, (2) reduces the formation of $\mathrm{NO}^{*}$ by two distinct mechanisms, i.e., prevention of the expression of iNOS protein and inhibition of iNOS activity, and (3) exerts many other effects, which appear to be unrelated to the inhibition of iNOS activity (nonspecific effects).

S-substituted isothioureas (ITUs) are non-amino acid analogs of L-arginine and also potent inhibitors of iNOS activity with variable isoform selectivity (131-133). For instance, $S$-ethylITU is a potent competitive inhibitor of all isoforms of human NOS, whereas $S$-aminoethylITU and $S$-methyl-ITU are more selective inhibitors of iNOS than of eNOS activity (132). In 1994, we demonstrated that $S$-methyl-ITU reverses the circulatory failure caused by endotoxin in the rat. The beneficial hemodynamic effect of $S$-methyl-ITU was associated with an attenuation of the liver injury and hepatocellular dysfunction caused by endotoxin in rats as well as an increase in the survival rate of mice challenged with high dose of endotoxin (131). Similarly, administration of aminoethyl-ITU ( $1 \mathrm{mg} / \mathrm{kg} / \mathrm{h}$ commencing $2 \mathrm{~h}$ after injection of endotoxin) results in beneficial hemodynamic effects and attenuates the degree of liver injury/dysfunction caused by endotoxin in the rat (134) (Fig. 5). In pigs with endotoxemia, injection of aminoethyl-ITU ( $10 \mathrm{mg} / \mathrm{kg}$ iv at $3 \mathrm{~h}$ after endotoxin) restores hepatic arterial blood flow (from reduced to normal levels) and increases hepatic oxygen consumption, without affecting cardiac output (135). Some of the beneficial effects of aminoguanidine in shock may not be due to its ability to inhibit iNOS activity. For instance, aminoethyl-ITU is a scavenger of peroxynitrite and exerts beneficial effects on models of disease/pathology known to be mediated by oxygen-derived free radicals (136). Interestingly, dimethyl-ITU (which does not inhibit iNOS activity) is a weak radical scavenger that inhibits the activation of the transcription factor NF- $\kappa \mathrm{B}$. In rats challenged with either endotoxin or live Salmonella typhimurium, dimethyl-ITU attenuates the formation of TNF- $\alpha$ and improves survival (137). It is conceivable that other S-substituted isothioureas will also prevent the activation of NF- $\mathrm{KB}$. This property may well explain why aminoethyl-ITU prevents the expression of iNOS protein caused by endotoxin in cultured macrophages and in the rat in vivo (130).

Recently, an analog of acetamidine termed 1400W [ $N$-(3-(aminomethyl)benzyl) acetamidine], has been reported to be an approx 5000-fold more potent inhibitor of iNOS activity than eNOS activity (human). The inhibition by $1400 \mathrm{~W}$ of the activity of human iNOS is potent $\left(K_{d}\right.$ value approx $\left.7 \mathrm{n} M\right)$, dependent on the cofactor NADPH and either irreversible or extremely slowly reversible. In a rat model of vascular injury caused by endotoxin, $1400 \mathrm{~W}$ is 50-fold more potent as an inhibitor of iNOS than eNOS activity and attenuates the vascular leak syndrome (138). Surprisingly, in a rat model of severe sepsis, $1400 \mathrm{~W}$ has been demonstrated to prevent the delayed circulatory failure, but not the liver injury/dysfunction caused by endotoxin. This finding supports the view that selective inhibition of iNOS activity might a useful approach in the restoration of blood pressure in patients with septic shock. Most notably, however, these data are consistent with the notion that - as in the case of iNOS knockout mice challenged with endotoxin (62) — enhanced formation of NO* by iNOS primarily contributes to the circulatory failure, but not to the liver injury/dysfunction caused by endotoxin. 


\section{INHIBITION OF NOS ACTIVITY in Humans with Septic Shock}

Although our understanding of the role of $\mathrm{NO}^{*}$ in animal models of circulatory shock has improved substantially over the past years, our knowledge regarding the biosynthesis and importance of $\mathrm{NO}^{\circ}$ in the pathophysiology of patients with SIRS or septic shock is still very limited. There is evidence that endotoxin and cytokines (when given in combination) cause the expression of iNOS as well as the formation of $\mathrm{NO}^{\circ}$ (nitrite/nitrate) in various human cells (primary or cell lines) including hepatocytes, mesangial cells, retinal pigmented epithelial cells, and lung epithelial cells $(139,140)$. Elevated plasma levels and urine levels of nitrite/ nitrate have been reported in adults and children with severe sepsis as well as in patients with burns who subsequently developed sepsis $(147,148)$. Moreover, elevated plasma levels of nitrite/ nitrate occur in patients receiving IL-2 chemotherapy (140). Interestingly, the increase in iNOS activity in leukocytes obtained from patients with sepsis appear to correlate with the number of failing organs, but not with blood pressure. Taken together, these studies support the view that severe sepsis/septic shock in humans is associated with an enhanced formation of $\mathrm{NO}^{\circ}$. However, it appears that the rise in the plasma levels of nitrite/nitrate in vivo in humans with septic shock is much smaller than in rodents (10-fold). Moreover, our understanding of (1) the biosynthesis of $\mathrm{NO}^{\circ},(2)$ the regulation of and the mechanism involved in the expression of iNOS, and (3) the role of NO in MODS in shock are largely based on animal experiments of septic shock in rodents. In contrast, relatively little is known about the role of $\mathrm{NO}^{\circ}$ in patients with septic and other forms of circulatory shock.

Early reports of beneficial hemodynamic effects of L-NMMA in humans with septic shock (141-144) stimulated a phase I, multicenter, open-label, dose-escalation $(1,2.5,5,10$, or $20 \mathrm{mg} / \mathrm{kg} / \mathrm{h}$ for up to $8 \mathrm{~h}$ ) study using L-NMMA (546C 88) in 32 patients with septic shock. In that study, L-NMMA sustained blood pressure and enabled a reduction in vasopressor (norepinephrine) support. The cardiac index fell to baseline values (possible due to an increase in peripheral vascular resistance) and left ventricular function was well maintained. Moreover, L-NMMA increased oxygen extraction, whereas pulmonary shunt was not worsened (145). A recent, placebo-controlled multicenter study involving 312 patients with septic shock has evaluated the effects of L-NMMA on the resolution of shock at $72 \mathrm{~h}$ (primary endpoint) (150). The severity of illness according to the SAPS II score was similar between placebo and the L-NMMA group. Infusion of L-NMMA enhanced mean arterial blood pressure and systemic vascular resistance index and decreased cardiac output (from elevated toward normal levels). L-NMMA had no effect on left ventricular systolic work index, indicating that the fall in cardiac output was not caused by an impairment in cardiac contractility. In patients treated with L-NMMA, there was a transient increase in mean pulmonary artery pressure. Interestingly, L-NMMA did not affects the thrombocytopenia or renal dysfunction caused by sepsis. Most notably, $41 \%$ of patients treated with L-NMMA, but only $21 \%$ of patients treated with placebo, recovered from shock within $72 \mathrm{~h}$. There was a strong trend for a reduction in mortality (at d 14) in patients treated with L-NMMA.

In 1997, Glaxo Wellcome started a phase III clinical trial evaluating the effect of 546C88 (targinine, L-NMMA) in patients with septic shock. That trial was stopped by the company (after an interim analysis) in spring 1998, because of "concerns about a higher mortality in the treated group than in the placebo group." The trial, which involved 177 centers from 26 countries, started in June 1997 and had enrolled 797 patients at the time of suspension. The interim analysis included data from 522 patients, 309 of whom had received 546C88. The data and safety-monitoring committee reported a trend toward increased mortality in the active treatment group and thus recommended stopping the trial because of patient safety concerns. The trial will not be resumed, and it is unlikely that development of the drug will continue (SCRIP, 1998; No. 2330, p. 21). 


\section{CONCLUDING REMARKS}

Since 1990, numerous studies have documented an enhanced formation of NO ${ }^{*}$ in various animal models of endotoxin and septic shock. Similarly, patients with septic shock exhibit elevated plasma levels of nitrite/nitrate. Although the enhanced formation of NO in animals and humans with septic shock contributes to hypotension and hyporeactivity of the vasculature to vasoconstrictor agents (vasoplegia), it is still unclear whether NO* (from iNOS) contributes to the organ dysfunction/failure syndrome associated with severe septic shock. The finding that the highly selective inhibitor of iNOS activity, $1400 \mathrm{~W}$, attenuates the delayed hypotension, but does not affect the multiple organ dysfunction caused by endotoxin in the rat, supports the view that an enhanced formation of $\mathrm{NO}^{-}$within the vasculature contributes to the circulatory failure, but does not directly contribute to the development of organ injury. This notion is supported by the finding that iNOS knockout mice elicit less hypotension but do develop liver injury when challenged with endotoxin.

Although there is evidence that human cells/tissue can, in principle, induce iNOS protein and activity (when challenged with endotoxin and cytokines), the degree of iNOS activity in patients with septic shock appears to be substantially lower than in some animal species (e.g., rodents). The finding that inhibition of NOS activity with L-NMMA in patients with septic shock exerted beneficial hemodynamic effects but did not affect, or even tended to increase, mortality rate is somewhat not surprising, as L-NMMA is only a moderately selective inhibitor of iNOS activity. Whether highly selective inhibitors of iNOS activity do not only exert beneficial hemodynamic effects but also decrease mortality rate in patients with septic shock deserves further investigations.

There is increasing evidence - derived primarily from in vitro studies - that the activation of the transcription factor NF- $\mathrm{KB}$ plays a pivotal role in local or systemic inflammation. The finding that inhibition of the activation of NF- $\kappa B$ by calpain inhibitor I attenuates the circulatory failure and the multiple organ dysfunction syndrome caused by endotoxin in the rat may represent a novel approach for the therapy of circulatory shock.

\section{REFERENCES}

1. Parrillo JE. Septic shock in humans: clinical evaluation, pathogenesis, and therapeutic approach. In: Shoemaker W, Ayres S, Grenuik A, Holbrook P, Thompson W, ed. Textbook of Critical Care, 2nd ed. Saunders, Philadelphia, 1989, p. 1006.

2. Morbidity and Mortality Weekly Report. Increase in national hospital discharge survey rates for septicemia-United States. 1979-1987. MMWR 1988;89:31-34.

3. Dunn D. Immunotherapeutic advances in the treatment of gram-negative sepsis. World J Surg 1987; 11:233-240.

4. Young L. Gram negative sepsis. In: Mandell GL, et al., eds. Principles and Practice of Infectious Disease. Churchill Livingston, New York, 1990, pp. 611-636.

5. Parker M, Parrillo JE. Septic shock: hemodynamics and pathogenesis. JAMA 1983;250:3324-3327.

6. Sprung CL, Caralis PV, Marcial EH, Pierce M, Gelbard MA, Long WM, et al. The effects of high-dose corticosteroids in patients with septic shock. A prospective, controlled study. N Engl J Med 1984;311: $1137-1143$.

7. Baue AE. The multiple organ or system failure syndrome. In: Schlag G, Redl H, eds. Pathophysiology of Shock, Sepsis, and Organ Failure. Springer Verlag, Berlin, 1993, pp. 1004-1018.

8. Groeneveld AB, Nauta JJ, Thijs LG. Peripheral vascular resistance in septic shock: its relation to outcome. Intensive Care Med 1988;14:141-147.

9. Dal Nogare AR. Southwestern internal medicine conference: septic shock. Am J Med Sci 1991;302: $50-65$.

10. Rietschel ET, Brade H. Bacterial endotoxins. Sci Am 1992;267:54-61.

11. Springer TA. Adhesion receptors of the immune system. Nature 1990;346:425-434.

12. De Kimpe SJ, Kengatharan M, Thiemermann C, Vane JR. The cell wall components peptidoglycan and lipoteichoic acid from Staphylococcus aureus act in synergy to cause shock and multiple organ failure. Proc Natl Acad Sci USA 1995;92:10,359-10,363. 
13. Wicken AJ, Knox KW. Bacterial cell surface amphiphiles. Biochim Biophys Acta 1980;604:1-26.

14. Barnes PF, Chatterjee D, Abrams JS, Lu S, Wang E, Yamamura M, et al. Cytokine production induced by Mycobacterium tuberculosis lipoarabinomannan. Relationship to chemical structure. J Immunol 1992;149:541-547.

15. Deitsch EA. Multiple organ failure: pathophysiology and potential future therapy. Ann Surg 1992;216: 117-134.

16. Latini R, Bianchi M, Correale E, Dinarello CA, Fantuzzi G, Fresco C, et al. Cytokines in acute myocardial infarction: selective increase in circulating tumor necrosis factor, its soluble receptor, and interleukin-1 receptor antagonist. J Cardiovasc Pharmacol 1994;23:1-6.

17. McKenna RM, Macdonald C, Bernstein KN, Rush DN. Increased production of tumor necrosis factor activity by hemodialysis but not peritoneal dialysis patients. Nephron 1994;67:190-196.

18. Testa M, Yeh M, Lee P, Fanelli R, Loperfido F, Berman JW, et al. Circulating levels of cytokines and their endogenous modulators in patients with mild to severe congestive heart failure due to coronary artery disease or hypertension. J Am Coll Cardiol 1996;28:964-971.

19. Okusawa S, Gelfand JA, Ikejima T, Connolly RJ, Dinarello CA. Interleukin 1 induces a shock-like state in rabbits. Synergism with tumor necrosis factor and the effect of cyclooxygenase inhibition. J Clin Invest 1988;81:1162-1172.

20. Tracey KJ. Tumor necrosis factor (cachectin) in the biology of septic shock syndrome. Circ Shock 1991;35:123-128.

21. Billiau A, Vandekerckhove F. Cytokines and their interactions with other inflammatory mediators in the pathogenesis of sepsis and septic shock. Eur J Clin Invest 1991;21:559-573.

22. Mozes T, Ben-Efraim S, Tak CJ, Heiligers JP, Saxene PR, Bonta IL. Serum levels of tumor necrosis factor determine the fatal or non-fatal course of endotoxic shock. Immunol Lett 1991;27:157-162.

23. Dinarello CA. Cytokines as mediators in the pathogenesis of septic shock. Curr Top Micobiol Immunol 1996;216:133-165.

24. Beutler B, Milsark IW, Cerami AC. Passive immunization against cachectin/tumor necrosis factor protects mice from lethal effect of endotoxin. Science 1985;229:869-871.

25. Fletcher DS, Agarwal L, Chapman KT. A synthetic inhibitor of interleukin-1 beta converting enzyme prevents endotoxin-induced interleukin-1 beta production in vitro and in vivo. J Interferon Cytokine Res 1995; 15:243-248.

26. Stuber F, Petersen M, Bokelmann F, Schade UA. Genomic polymorphism within the tumor necrosis factor locus influences plasma tumor necrosis factor-alpha concentrations and outcome of patients with severe sepsis. Crit Care Med 1996;24:381-384.

27. Douzinas EE, Tsidemiadou PD, Pitaridis MT, Andrianakis I, Bobota-Chloraki A, Katsouyanni K, et al. The regional production of cytokines and lactate in sepsis-related multiple organ failure. Am J Respir Crit Care Med 1997;155:53-59.

28. Roumen RM, Hendriks T, van der Ven-Jongekrijg J, Nieuwenhuijzen GA, Sauerwein RW, van der Meer JW, et al. Cytokine patterns in patients after major vascular surgery, hemorrhagic shock, and severe blunt trauma. Relation with subsequent adult respiratory distress syndrome and multiple organ failure. Ann Surg 1993;218:769-776.

29. Schade UF. Pentoxifylline increases survival in murine endotoxin shock and decreases formation of tumor necrosis factor. Circ Shock 1990;31:171-181.

30. Tracey KJ, Fong Y, Hesse DG, Manogue KR, Lee AT, Kuo GC, et al. Anti-cachectin/TNF monoclonal antibodies prevent septic shock during lethal bacteraemia. Nature 1987;330:662-664.

31. Wakabayashi G, Gelfand JA, Burke JF, Thompson RC, Dinarello CA. A specific receptor antagonist for interleukin 1 prevents Escherichia coli-induced shock in rabbits. FASEB J 1991;5:338-343.

32. Abraham E, Wunderink R, Silverman H, Perl TM, Nasraway S, Levy H, et al. Efficacy and safety of monoclonal antibody to human tumor necrosis factor-alpha in patients with sepsis syndrome. A randomized, controlled, double-blind, multicenter trial. TNF-alpha Mab Sepsis Study Group. JAMA 1995;273:934-941.

33. Dhainaut JF, Vincent JL, Richard C, Lejeune P, Martin C, Fierobe L, et al. CDP571, a humanized antibody to tumor necrosis factor-alpha safety, pharmacokinetics, immune response, and influence of the antibody on cytokine concentrations in patients with septic shock. CPD571 Sepsis Study Group. Crit Care Med 1995;23:1461-1469.

34. Cohen J, Carlet J. INTERSEPT: an international, multicenter, placebo-controlled trial of monoclonal antibody to human tumor necrosis factor-alpha in patients with sepsis. International Sepsis Trial Study Group. Crit Care Med 1996;24:1431-1440.

35. Reinhart K, Wiegand-Lohnert C, Grimminger F, Kaul M, Withington S, Treacher D, et al. Assessment of the safety and efficacy of the monoclonal anti-tumor necrosis factor antibody-fragment, MAK 195F, 
in patients with sepsis and septic shock: a multi-center, randomized, placebo-controlled, dose-ranging study. Crit Care Med 1996;24:733-742.

36. Fisher CJ Jr, Agosti JM, Opal SM, Lowry SF, Balk RA, Sadoff JC, et al. Treatment of septic shock with the tumor necrosis factor receptor:Fc fusion protein. The soluble TNF Receptor Sepsis Study Group. N Engl J Med 1996;334:1697-1702.

37. Fisher CJ Jr, Dhainaut JF, Opal SM, Pribble JB, Balk RA, Slotman GJ, et al. Recombinant human interleukin 1 receptor antagonist in the treatment of patients with sepsis syndrome. Results from a randomized, double-blind, placebo controlled trial. Phase III rhIL-1 ra Sepsis Syndrome Study Group. JAMA 1994;271:1836-1843.

38. Knaus WA, Harrell FE Jr, LaBrecque JF, Wagner DP, Pribble JP, Draper EA, et al. Use of predicted risk of mortality to evaluate the efficacy of anti-cytokine therapy in sepsis. The rhIL-1ra Phase III Sepsis Syndrome Study Group. Crit Care Med 1996;24:46-56.

39. Smith SR, Calzetta A, Bankowski J, Kenworthy-Bott L, Terminelli C. Lipopolysaccharide-induced cytokine production and mortality in mice treated with Corynebacterium parvum. J Leukoc Biol 1993; 54:23-29.

40. Cross AS, Opal SM, Palardy JE, Bodmer MW, Sadoff JC. The efficacy of combination immunotherapy in experimental Pseudomonas sepsis. J Infect Dis 1993;167:112-118.

41. Ruetten H, Thiemermann C. Combination immunotherapy which neutralises the effects of TNF alpha and IL-1 beta attenuates the circulatory failure and multiple organ dysfunction caused by endotoxin in the rat. J Physiol Pharmacol 1997;48:605-621.

42. Opal SM, Cross AS, Jhung JW, Young LD, Palardy JE, Parejo NA, et al. Potential hazards of combination immunotherapy in the treatment of experimental septic shock. J Infect Dis 1996;173: $1415-1421$.

43. Heinzel FP. The role of IFN-gamma in the pathology of experimental endotoxemia. J Immunol 1990; 145:2920-2924.

44. Moncada S, Palmer RM, Higgs EA. Nitric oxide: physiology, pathophysiology, and pharmacology. Pharmacol Rev 1991;43:109-142.

45. Forstermann U, Pollock JS, Schmidt HH, Heller M, Murad F. Calmodulin-dependent endotheliumderived relaxing factor/nitric oxide synthase activity is present in the particulate and cytosolic fraction of bovine aortic endothelial cells. Proc Natl Acad Sci USA 1991;88:1788-1792.

46. Leone AM, Palmer RM, Knowles RG, Francis P, Ashton DS, Moncada S. Constitutive and inducible nitric oxide synthases incorporate molecular oxygen into both nitric oxide and citrulline. J Biol Chem 1991;266:23,790-23,795.

47. Marletta MA. Nitric oxide synthase structure and mechanism. J Biol Chem 1993;268:12,231-12,334.

48. Feldman PL, Griffith OW, Stuehr DJ. The surprising life of nitric oxide. Chem Eng News 1993; Dec. 20:26-38.

49. Gross SS, Stuehr DJ, Aisaka K, Jaffe EA, Levi R, Griffith OW. Macrophage and endothelial cell nitric oxide synthesis: cell-type selective inhibition by $\mathrm{N}^{\mathrm{G}}$-aminoarginine, $\mathrm{N}^{\mathrm{G}}$-nitroarginine and $\mathrm{N}^{\mathrm{G}}$-methylarginine. Biochem Biophys Res Commun 1990;170:96-103.

50. Lambert LE, French JF, Whitten JP, Baron BM, McDonald IA. Characterization of cell selectivity of two novel inhibitors of nitric oxide synthesis. Eur J Pharmacol 1992;216:131-134.

51. Feldman PL, Griffith OW, Hong H, Stuehr DJ. Irreversible inactivation of macrophage and brain nitric oxide synthase by L-NG-methylarginine requires NADPH-dependent hydroxylation. J Med Chem 1993;36:491-496.

52. Nathan C. Nitric oxide as a secretory product of mammalian cells. FASEB J 1992;6:3051-3064.

53. Green SF, Nacy CA. Antimicrobial and immunophatologic effects of cytokine-induced nitric oxide synthesis. Curr Opin Infect Dis 1993;6:384-396.

54. Schott CA, Gray GA, Stoclet JC. Dependence of endotoxin-induced vascular hyporeactivity ON extracellular L-arginine. Br J Pharmacol 1993;108:38-43.

55. Kilbourn RG, Jubran A, Gross SS, Griffith OW, Levi R, Adams J, et al. Reversal of endotoxinmediated shock by NG-methyl-L-arginine, an inhibitor of nitric oxide synthesis. Biochem Biophys Res Commun 1990;172:1132-1138.

56. Thiemermann C, Vane JR. Inhibition of nitric oxide synthesis reduces the hypotension induced by bacterial lipopolysaccharide in the rat in vivo. Eur J Pharmacol 1990;182:591-595.

57. Julou-Schaeffer G, Gray GA, Fleming I, Schott C, Parratt JR, Stoclet JC. Loss of vascular responsiveness induced by endotoxin involves the L-arginine pathway. Am J Physiol 1990;259:H1038-H1043.

58. Rees DD, Cellek S, Palmer RM, Moncada S. Dexamethasone prevents the induction by endotoxin of nitric oxide synthase and the associated effects on vascular tone: an insight into endotoxin shock. Biochem Biophys Res Commun 1990;173:541-547. 
59. Billiar TR, Curran RD, Harbrecht BG, Stuehr DJ, Demetris AJ, Simmons RL. Modulation of nitrogen oxide synthesis in vivo: NG-monomethyl-L-arginine inhibits endotoxin-induced nitrate/nitrate biosynthesis while promoting hepatic damage. J Leukoc Biol 1990;48:565-569.

60. Szabo C, Thiemermann C. Regulation of the expression of the inducible isoform of nitric oxide synthase. Adv Pharmacol 1995;34:113-153.

61. Thiemermann C. The role of the L-arginine: nitric oxide pathway in circulatory shock. Adv Pharmacol 1994;28:45-79.

62. MacMicking JD, Nathan C, Hom G, Chartrain N, Fletcher DS, Trumbauer M, et al. Altered responses to bacterial infection and endotoxic shock in mice lacking inducible nitric oxide synthase. Cell 1995; 81:641-650.

63. Wei XQ, Charles IG, Smith A, Ure J, Feng GJ, Huang FP, et al. Altered immune responses in mice lacking inducible nitric oxide synthase. Nature 1995;375:408-411.

64. Xie Q, Whisnant R, Nathan C. Promotor of the mouse gene encoding calcium-independent nitric oxide synthase confers inducibility by interferon gamma and bacterial lipopolysaccharide. J Exp Med 1993; 177:1779-1784.

65. Sherman MP, Aeberhard EE, Wong VZ, Griscavage JM, Ignarro LJ. Pyrrolidine dithiocarbamate inhibits induction of nitric oxide synthase activity in rat alveolar macrophages. Biochem Biophys Res Commun 1993;191:1301-1308.

66. Griscavage JM, Wilk S, Ignarro LJ. Serine and cysteine proteinase inhibitors prevent nitric oxide production by activated macrophages by interfering with transcription of the inducible NO synthase gene. Biochem Biophys Res Commun 1995;215:721-729.

67. Dong Z, Qi X, Fidler IJ. Protein tyrosine kinase inhibitors decrease the induction of nitric oxide synthase activity in lipopolysaccharide-responsive and non-responsive murine macrophages. J Immunol 1993; 151:2717-2724.

68. Salzman A, Denenberg AG, Ueta I, O'Conner M, Linn SC, Szabo C. Induction and activity of nitric oxide synthase in cultured human intestinal epithelial monolayers. Am J Physiol 1996;270: G565-G573.

69. Joly GA, Ayres M, Kilbourn RG. Potent inhibition of inducible nitric oxide synthase by geldanamycin, a tyrosine kinase inhibitor, in endothelial, smooth muscle cells, and in rat aorta. FEBS Lett 1997; 403:40-44.

70. Diaz-Guerra MJ, Bodelon OG, Velasco M, Whelan R, Parker PJ, Bosca L. Up-regulation of protein kinase C-epsilon promotes the expression of cytokine-inducible nitric oxide synthase in RAW 264.7 cells. J Biol Chem 1996;271:32,028-32,033.

71. Radomski MW, Palmer RM, Moncada S. Characterization of the L-arginine: nitric oxide pathway in human platelets. Br J Pharmacol 1990;101:325-330.

72. Schini VB, Catovski S, Scott-Burden T, Vanhoutte P. The inducible nitric oxide synthase is impaired by thrombin in vascular smooth muscle cells. J Cardiovasc Pharmacol 1992;20:S142-S144.

73. Doyle AG, Herbein G, Montaner LJ, Minty AJ, Caput D, Ferrara P, et al. Interleukin-13 alters the activation state of murine macrophages in vitro: comparison with interleukin-4 and interferon-gamma. Eur J Immunol 1994;24:1441-1445.

74. Hirahashi J, Nakaki T, Hishikawa K, Marumo T, Yasumori T, Hayashi M, et al. Endothelin-1 inhibits induction of nitric oxide synthase and GTP cyclohydrolase I in rat mesangial cells. Pharmacology 1996;53:241-249.

75. Saura M, Martinez-Dalmau R, Minty A, Perez-Sala D, Lamas S. Interleukin-13 inhibits inducible nitric oxide synthase expression in human mesangial cells. Biochem J 1996;313:641-646.

76. Ruetten H, Thiemermann C. Effects of tyrphostins and genistein on the circulatory failure and organ dysfunction caused by endotoxin in the rat: a possible role for protein tyrosine kinase. Br J Pharmacol 1997;122:59-70.

77. Xie Q, Kashiwabara Y, Nathan C. Role of transcription factor NF-(B/Rel) in induction of nitric oxide. J Biol Chem 1994;269:4705-4708.

78. Koide M, Kawahara Y, Nakayama I, Tsuda T, Yokoyama M. Cyclic AMP-elevating agents induce an inducible type of nitric oxide synthase in cultured vascular smooth muscle cells. Synergism with the induction elicited by inflammatory cytokines. J Biol Chem 1993;268:24,959-24,966.

79. Kunz D, Walker G, Wiesenberg I, Pfeilschifter J. Inhibition by tetranactin of interleukin 1 beta- and cyclic AMP-induced nitric oxide synthase expression in rat renal mesangial cells. Br J Pharmacol 1996;118:1621-1626.

80. Bulut V, Severn A, Liew FY. Nitric oxide production by murine macrophages is inhibited by prolonged elevation of cyclic AMP. Biochem Biophys Res Commun 1993;195:1134-1138.

81. Assreuy J, Cunha FQ, Liew FY, Moncada S. Feedback inhibition of nitric oxide synthase activity by nitric oxide. Br J Pharmacol 1993;108:833-837. 
82. Nussler AK, Billiar TR. Inflammation, immunoregulation, and inducible nitric oxide synthase. J Leukoc Biol 1993;54:171-178.

83. Levitzki A, Gazit A. Tyrosine Kinase inhibition: an approach to drug development. Science 1995; 267:1782-1788.

84. Weinstein SL, Gold MR, De Franco AL. Bacterial lipopolysaccharide stimulates protein tyrosine phosphorylation in macrophages. Proc Natl Acad Sci USA 1991;88:4148-4152.

85. Geng Y, Zhang B, Lotz M. Protein tyrosine kinase activation is required for lipopolysaccharide induction of cytokines in human blood monocytes. J Immunol 1993;151:6692-6700.

86. Evans JPM, Mire-Sluis AR, Hoffbrand AV, Wickremasinghe RG. Binding of G-CSF, GM-CSF, tumor necrosis factor-alpha and gamma-interferon to cell surface receptors on human myeloid leukemia cells triggers rapid tyrosine and serine phosphorylation of a 75-Kd protein. Blood 1990;75:88-95.

87. Kohno M, Nishizawa N, Tsujimoto M, Nomoto H. Mitogenic signalling pathway of tumor necrosis factor involves the rapid tyrosine phosphorylation of 41000-M(r) and 43000-M(r) cytosol proteins. Biochem J 1990;267:91-98.

88. Novogrodsky A, Vanichkin A, Patya M, Gazit A, Osherov N, Levitzki A. Prevention of lipopolysaccharide-induced lethal toxicity by tyrosine kinase inhibitors. Science 1994;264:1319-1322.

89. Vanichikin A, Patya M, Gazit A, Levitzki A, Novogrodsky A. Late administration of a lipophylic tyrosine kinase inhibitor prevents lipopolysaccharide and Escherichia coli-induced lethal toxicity. J Infect Dis 1996;173:927-933.

90. Nabel G, Baltimore D. An inducible transcription factor activates expression of human immunodeficiency virus in T cells. Nature 1987;326:711-713.

91. Grimm S, Bauerle PA. The inducible transcription factor NF-kappa B: structure function relationship of its protein subunit. Biochem J 1993;290:297-308.

92. Sen R, Baltimore D. Inducibility of kappa immunoglobulin enhancer binding protein NF-kappa B by a posttranslation mechanism. Cell 1986;47:921-928.

93. Lowenthal JW, Ballard DW, Boehnlein E, Greene WC. Tumor necrosis factor alpha induces proteins that bind specifically to kappa B-like enhancer elements and regulate interleukin 2 receptor alphachain gene expression in primary human T lymphocytes. Proc Natl Acad Sci USA 1989;86:2331-2335.

94. Arima N, Kuziel WA, Gardine TA, Greene WC. Il-2-induced signal transduction involves the activation of nuclear NF-kappa B expression. J Immunol 1992;149:83-91.

95. Henkel T, Machleidt T, Alkalay I, Kroenke M, Ben-Neriah Y, Bauerle PA. Rapid proteolysis of IкB$\alpha$ is necessary for activation of transcription factor NF- $\kappa$ B. Nature 1993;365:182-185.

96. Siebenlist U, Franzoso G, Brown K. Structure, regulation and function of NF-kappa B. Annu Rev Cell Biol 1994;10:405-455.

97. Baeuerle PA, Baltimore D. Activation of DNA-binding activity in an apparently cytoplasmic precursor of the NF-kappa B transcription factor. Cell 1988;53:211-217.

98. Baeuerle PA, Baltimore D. I kappa B: a specific inhibitor of the NF-kappa B transcription factor. Science 1988;242:540-546.

99. Sun SC, Ganchi PA, Ballard DW, Greene WC. NF-kappa B controls expression of inhibitor I kappa B alpha: evidence for an inducible autoregulatory pathway. Science 1993;259:1912-1915.

100. Miyamoto S, Maki M, Schmitt MJ, Hatanaka M, Verma IM. Tumor necrosis factor $\alpha$-induced phosphorlyation of $\mathrm{I} \kappa \mathrm{B}-\alpha$ is a signal for its degradation but not dissociation from NF- $\kappa \mathrm{B}$. Proc Natl Acad Sci USA 1994;91:12,740-12,744.

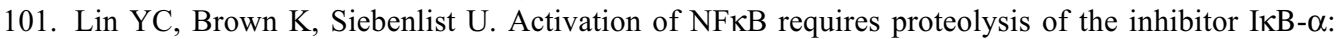

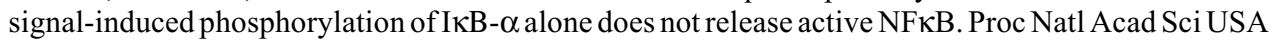
1995;92:552-556.

102. Barnes PJ, Karin M. Nuclear factor-kappaB: a pivotal transcription factor in chronic inflammatory diseases. N Engl J Med 1997;336:1066-1071.

103. Ruetten H, Thiemermann C. Attenuation by calpain inhibitor I, an inhibitor of the proteolysis of I $\mathrm{KB}$, of the circulatory failure and multiple organ dysfinction caused by endotoxin in the rat. Br J Pharmacol 1997;121:695-704.

104. Radomski MW, Palmer RM, Moncada S. Glucocorticoids inhibit the expression of an inducible, but not the constitutive, nitric oxide synthase in vascular endothelial cells. Proc Natl Acad Sci USA 1990; 87:10,043-10,047.

105. Kwon G, Corbett JA, Rodi CP, Sullivan P, McDaniel ML. Interleukin-1 beta-induced nitric oxide synthase expression by rat pancreatic beta-cells: evidence for the involvement of nuclear factor kappa $\mathrm{B}$ in the signaling mechanism. Endocrinology 1995;136:4790-4795.

106. Nishiya T, Uehara T, Nomura Y. Herbimycin A suppresses NF-kappa B activation and tyrosine phosphorylation of JAK2 and the subsequent induction of nitric oxide synthase in C6 glioma cells. FEBS Lett 1995;371:333-336. 
107. Mahon TM, O'Neill LA. Studies into the effect of the tyrosine kinase inhibitor herbimycin A on NFkappa $\mathrm{B}$ activation in T lymphocytes. Evidence for covalent modification of the p50 subunit. Biochem J 1995;270:28,557-28,564.

108. Yokoo T, Katamura M. Dual regulation of IL-1 beta-mediated matrix metalloproteinase-9 expression in mesangial cells by NF-kappa B and AP-1. Am J Physiol 1996;270:F123-F130.

109. Tetsuka T, Srivastava SK, Morrison AR. Tyrosine kinase inhibitors, genistein and herbimycin A, do not block interleukin-1 beta-induced activation of NF-kappa B in rat mesangial cells. Biochem Biophys Res Commun 1996;26:808-812.

110. Imbert V, Rupec RA, Livolsi A, Pahl HL, Traenckner EB, Mueller-Dieckmann C, et al. Tyrosine phosphorylation of I kappa B-alpha activates NF-kappa B without proteolytic degrdation of I kappa B-alpha. Cell 1996;86:787-798.

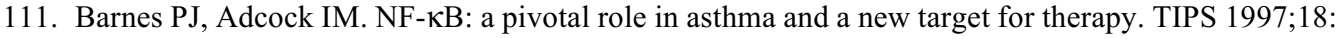
$46-50$.

112. Wright CE, Rees DD, Moncada S. Protective and pathological roles of nitric oxide in endotoxin shock. Cardiovasc Res 1992;26:48-57.

113. Paya D, Gray GA, Fleming I, Stoclet JC. Effect of dexamethasone on the onset and persistence of vascular hyporeactivity induced by E. coli lipopolysaccharide in rats. Circ Shock 1993;41:103-112.

114. Estrada C, Gomez C, Martin C, Moncada S, Gonzalez C. Nitric oxide mediates tumor necrosis factoralpha cytotoxicity in endothelial cells. Biochem Biophys Res Commun 1992;186:475-482.

115. Palmer RM, Bridge L, Foxwell NA, Moncada S. The role of nitric oxide in endothelial cell damage and its inhibition by glucocorticoids. Br J Pharmacol 1992;105:11,12.

116. Morris SM Jr, Billiar TR. New insights into the regulation of inducible nitric oxide synthesis. Am J Physiol 1994;266:E829-E839.

117. Southan GJ, Szabo C. Selective pharmacological inhibition of distinct nitric oxide synthase isoforms. Biochem Pharmacol 1996;51:383-394.

118. Wu CC, Ruetten $\mathrm{H}$, Thiemermann C. Comparison of the effects of aminoguanidine and $\mathrm{N}^{\omega}$-nitro-Larginine methyl ester on the multiple organ dysfunction caused by endotoxaemia. Eur J Pharmacol 1996;300:99-104.

119. Walder CE, Thiemermann C, Vane JR. The involvement of endothelium-derived relaxing factor in the regulation of renal cortical blood flow in the rat. Br J Pharmacol 1991;102:967-973.

120. Robertson FM, Offner PJ, Ciceri DP, Becker WK, Pruitt BA Jr. Detrimental hemodynamic effects of nitric oxide synthase inhibition in septic shock. Arch Surg 1994;129:149-156.

121. Corbett JA, Tilton RG, Chang K, Hasan KS, Ido Y, Wang JL, et al. Aminoguanidine, a novel inhibitor of nitric oxide formation, prevents diabetic vascular dysfunction. Diabetes 1992;41:552-556.

122. Wu CC, Chen SJ, Szabo C, Thiemermann C, Vane JR. Aminoguanidine attenuates the delayed circulatory failure and improves survival in rodent models of endotoxic shock. Br J Pharmacol 1995;114: $1666-1672$.

123. Seo HG, Fujiwara N, Kaneto H, Asahi M, Fujii J, Taniguchi N. Effect of a nitric oxide synthase inhibitor, S-ethylisothiourea, on cultured cells and cardiovascular functions of normal and lipopolysaccharide-treated rabbits. J Biochem (Tokyo) 1996;119:553-558.

124. Ruetten H, Southan GJ, Abate A, Thiemermann C. Attenuation of endotoxin-induced multiple organ dysfunction by 1-amino-2-hydroxy-guanidine, a potent inhibitor of inducible nitric oxide synthase. $\mathrm{Br}$ J Pharmacol 1996;118:261-270.

125. Arkovitz MS, Wispe JR, Garcia VF, Szabo C. Selective inhibition of the inducible isoform of nitric oxide synthase prevents pulmonary transvascular flux during acute endotoxemia. J Pediatr Surg 1996; 31:1009-1015.

126. Bieganski T, Kusche J, Lorenz W, Hesterberg R, Stahlknecht CD, Feussner KD. Distribution and properties of human intestinal diamine oxidase and its relevance for the histamine catabolism. Biochim Biophys Acta 1983;756:196-203.

127. Seiler N, Bolkenius FN, Knodgen B. The influence of catabolic reactions on polyamine excretion. Biochem J 1985;225:219-226.

128. Edelstein D, Brownlee M. Aminoguanidine ameliorates albuminuria in diabetic hypertensive rats. Diabetologia 1992;35:96,97.

129. Ou P, Wolff SP. Aminoguanidine: a drug proposed for prophylaxis in diabetes inhibits catalase and generates hydrogen peroxide in vitro. Biochem Pharmacol 1993;46:1139-1144.

130. Ruetten H, Thiemermann C. Prevention of the expression of inducible nitric oxide synthase by aminoguanidine or aminoethyl-isothiourea in macrophages and in the rat. Biochem Biophys Res Commun 1996;225:525-530. 
131. Szabo C, Southan GJ, Thiemermann C. Beneficial effects and improved survival in rodent models of shock with S-methyl-isothiourea, a novel, potent and selective inhibitor of inducible nitric oxide synthase. Proc Natl Acad Sci USA 1994;91:12,472-12,476.

132. Southan GJ, Szabo C, Thiemermann C. Isothioureas: potent inhibitors of nitric oxide synthases with variable isoform selectivity. Br J Pharmacol 1995;114:510-516.

133. Garvey EP, Oplinger JA, Tanoury GJ, Sherman PA, Fowler M, Marshall S, et al. Potent and selective inhibition of human nitric oxide synthases. Inhibition by non-amino acid isothioureas. J Biol Chem 1994;269:26,669-26,676.

134. Thiemermann C, Ruetten H, Wu CC, Vane JR. The multiple organ dysfunction syndrome caused by endotoxin in the rat: attenuation of liver dysfunction by inhibitors of nitric oxide synthase. $\mathrm{Br} \mathrm{J}$ Pharmacol 1995;116:2845-2851.

135. Saetre T, Gundersen Y, Thiemermann C, Lilleaasen P, Aasen AO. Aminoethyl-isothiourea, a selective inhibitor of inducible nitric oxide synthase activity, improves liver circulation and oxygen metabolism in a porcine model of endotoxemia. Shock 1998;9:109-115.

136. Thiemermann C. Nitric oxide and septic shock. Gen Pharmacol 1997;29:159-166.

137. Sprong RC, Aarsman CJ, van Oirschot JF, van Asbeck BS. Dimethylthiourea protects rats against gram-negative sepsis and decreases tumor necrosis factor and nuclear factor kappaB activity. J Lab Clin Med 1997;129:470-481.

138. Garvey EP, Oplinger JA, Furfine ES, Kiff RJ, Laszlo F, Whittle BJ, et al. 1400W is a slow, tight binding, and highly selective inhibitor of inducible nitric-oxide synthase in vitro and in vivo. J Biol Chem 1997;272:4959-4963.

139. Morris SM Jr, Billiar TR. New insights into the regulation of inducible nitric oxide synthesis. Am J Physiol 1994;266:E829-E839.

140. Preiser JC, Vincent JL. Nitric oxide involvement in septic shock: Do human beings behave like rodents? In Vincent JL, ed. Yearbook of Intensive Care and Emergency Medicine. Springer Verlag, Berlin, 1996, pp. 358-365.

141. Petros A, Bennett D, Vallance P. Effect of nitric oxide synthase inhibitors on hypotension in patients with septic shock. Lancet 1991;338:1557,1558.

142. Schilling J, Cakmakci M, Battig U, Geroulanos S. A new approach in the treatment of hypotension in human septic shock by NG-monomethyl-L-arginine, an inhibitor of the nitric oxide synthetase. Intensive Care Med 1993;19:227-231.

143. Lorente JA, Landin L, De Pablo R, Renes E, Liste D. L-arginine pathway in the sepsis syndrome. Crit Care Med 1993;21:1287-1295.

144. Petros A, Lamb G, Leone A, Moncada S, Bennett D, Vallance P. Effects of a nitric oxide synthase inhibitor in humans with septic shock. Cardiovasc Res 1994;28:34-39.

145. Watson D, Donaldson J, Grover R, Mottola D, Guntipalli K, Vincent JL. The cardiopulmonary effects of 546C88 in human with septic shock. Int Care Med 1995;21:S117.

146. Shultz PJ, Raij I. Endogenously synthesized nitric oxide prevents endotoxin-induced glomerular thrombosis. J Clin Invest 1992;90:1718-1725.

147. Doughty LA, Kaplan SS, Carcillo JA. Inflammatory cytokine and nitric oxide responses in pediatric sepsis and organ failure. Crit Care Med 1996;24:1137-1143.

148. Preiser JC, Reper P, Vlasselaer D, Vray B, Zhang H, Metz G. et al. Nitric oxide production is increased in patients after burn injury. J Trauma 1996;40:368-371.

149. Tracey WR, Tse J, Carter G. Lipopolysaccharide-induced changes in plasma nitrite and nitrate concentrations in rats and mice: pharmacological evaluation of nitric oxide synthase inhibitors. J Pharmacol Exp Ther 1995;272:1011-1015.

150. Grover R, Zaccardelli D, Colice G, Guntupali K, Watson D, Vincent JL. An open-label dose escalation study of the nitric oxide synthase inhibitor, N(G)-methyl-L-arginine hydrochloride (546188), in patients with septic shock. Crit Care Med 1999;27:913-922. 